\title{
Gum Arabic as fetal hemoglobin inducing agent in sickle cell anemia; in vivo study
}

\author{
Lamis Kaddam ${ }^{*}$, Imad FdleAlmula², Omer Ali Eisawi ${ }^{3}$, Haydar Awad Abdelrazig ${ }^{4}$, Mustafa Elnimeiri ${ }^{5}$, \\ Florian Lang ${ }^{6}$ and Amal M. Saeed ${ }^{7}$
}

\begin{abstract}
Background: High levels of fetal haemoglobin (HbF) decrease sickle cell anaemia (SCA) severity and leads to improved survival. According to in vivo and in vitro studies, butyrate increases $\mathrm{HbF}$ production. Its utilization in clinical practice is hampered, however, by its short half-life. Serum butyrate concentrations could be enhanced by colonic bacterial fermentation of Gum Arabic (GA), edible, dried, gummy exudates from Acacia Senegal tree. We hypothesized that regular intake of GA increases serum butyrate levels, thus inducing HbF production and ameliorating symptoms of sickle cell anemia.
\end{abstract}

Methods: Fourty seven patients (5-42 years) carrying hemoglobin SS were recruited from April 2014 to January 2015. Patients received $30 \mathrm{~g} /$ day GA for 12 weeks. HbF, blood count and erythropoietin level were measured. The main outcome of interest was the level of HbF after 12 weeks. The secondary outcomes were improvement in clinical and laboratory results. The study was ethically approved by Alneelain University IRB.

Results: The study revealed significant increase in HbF level P.V0.000 [95 \% Cl, 0.43-1.02], MCV P.V:000 [95 \% Cl, 2.312-6.058] and Hematocrit level P.V:0.026 [95 \% Cl, 0.124-1.902]. No significant difference was encountered in platelets count P.V: 0.346 [95 \% Cl,-25.76-71.94], and WBCs count P.V:0.194 [95 \% Cl,-8.035-1.68]. Thirty seven percent of patients experienced minor side effects which resolved within a week.

Conclusion: These findings reveal a novel effect of GA, which may be used to foster fetal hemoglobin production.

Trial registration: ClinicalTrials.gov Identifier: NCT02467257. Registered 3rd June 2015.

\section{Background}

Homozygous sickle cell Anemia (SCA) is an autosomal recessive genetic disease that results from the substitution of valine for glutamic acid at position 6 of the $\beta$-globin chain, leading to production of hemoglobin $\mathrm{S}$ (HbS) [1]. HbS polymerizes in red blood cells upon deoxygenation. This causes the RBCs to change from biconcave disc shape to an irregular sickled shaped. Sickled RBCs can block blood vessels, and thus decrease the delivery of oxygen to organs and tissues. Sickled cells are extremely susceptible to hemolysis and eryptosis [2], causing chronic anemia [3]. Sickle cell disease (SCD) is the most common genetic disorder among people of African descent [4].

\footnotetext{
* Correspondence: lamiskaddam@hotmail.com

${ }^{1}$ Department of Physiology Faculty of Medicine, Alneelain University, P.O.

Box: 11121, Khartoum 12702, Sudan

Full list of author information is available at the end of the article
}

Fetal hemoglobin (HbF) expression is a crucial determinant of the clinical severity of SCD [5]. The percentage of $\mathrm{HbF}(\mathrm{HbF} \%)$ influences both laboratory values and clinical features of children and adults with sickle cell anemia [6]. These observations were largely responsible for the shift of therapeutic emphasis and strategies to increase the level of $\mathrm{HbF}$ in vivo in patients with sickle cell disease [1]. Hydroxyurea (HU) been approved by the FDA to treat adult sickle cell patients [7]. Still $\mathrm{HU}$ is underutilized because of concern regarding safety and lack of availability in many parts of the developing world [8]. In addition HU is expensive [9] and requires regular follow up to assess response and monitor toxicity, which restrict it is usage even more in low resources setting. Both in vivo and in vitro studies demonstrate that butyrate administration similarly increases Hemoglobin F production [10-14]. So far the chemical derivatives of butyrate are of less clinical value because 
of their low bioavailability and rapid metabolism [8]. Arginine butyrate had to be given by continuous intravenous infusion in large volumes, and sodium phenylbutyrate required as many as 40 tablets daily [8]. Butyrate could, however, be generated from Gum Arabic (GA), edible, dried, gummy exudates from the stems and branches of Acacia Senegal and Acacia Seyal, rich in non-viscous soluble fiber. It is defined by the FAO/WHO Joint Expert Committee for Food Additives (JECFA) as a dried exudation obtained from the stem of A. Senegal [15]. GA has wide industrial uses as a stabilizer, thickening agent and emulsifier, mainly in the food industry (e.g. in soft drinks syrup, gummy candies and marshmallows). The US FDA recognized it as one of the safest dietary fibres $[15,16]$. GA is indigestible for both human and animals; Its fermentation by colonic intestinal bacteria leads to formation of various degradation products, such as short-chain fatty acids [17]. Gum Arabic ingestion increases serum short chain fatty acid concentration, mainly butyrate and propionate $[15,18]$. Serum butyrate concentration increased following administration of GA in healthy subjects $[15,19]$. Oral intake of GA has been shown to provide several health benefits [20], such as prebiotic effects [16]. GA significantly increases Bifidobacteria, Lactobacteria, and Bacteriodes in the gut [16]. GA is claimed to have anti-cancer [16], anti-malarial [17] immune-modulatory $[17,21]$ and antioxidant effects $[15,16,22]$. GA treatment has been shown to favorably influence clinical and laboratory results in rats with adenine-induced chronic renal failure CRF and in humans diagnosed with renal failure $[15,17,21]$. GA shown to increase Erythropoietin level In two separate studies and ameliorated anemia caused by adenine administration [23, 24].

We hypothesized GA degradation delivers short chain fatty acids, which in turn have been shown to stimulate fetal hemoglobin expression in RBCs. Increased levels of erythrocyte fetal hemoglobin are known to hinder the intraerythrocytic $\mathrm{HbS}$ polymerization and provide some protection against hemolysis and vaso-occlusive crisis [5]. The present study tested whether Gum Arabic may influence the clinical course of SCD.
To the best of our knowledge this is the first study conducted to investigate the effect of oral administration of GA on fetal hemoglobin production in sickle cell anemia patients.

\section{Methods}

This is an experimental study with the aim to produce primary data for hematological efficacy of oral intake of Gum Arabic as fetal hemoglobin inducer in sickle cell anemia patients. The participants were recruited from the out patients clinic of pediatric and adult hematology units in Military hospital-Khartoum-Sudan. Inclusion criteria were: patients homozygous for SCD (SS) as documented by Hemoglobin electrophoreses, aged between 5 and 50 years. The total number of participants recruited mounted to 47. All medications and dosages had been stable for 2 weeks before study entry. All participants received folic acid $5 \mathrm{mg}$ daily to support erythropoiesis. Exclusion criteria: patients received blood transfusion within the last 3 months or admitted to the hospital within 2 weeks because of SCD-related events or crisis. Ethical clearance was obtained from the Institutional Review Board at Alneelain University and from Research Ethics Committee- Khartoum State Ministry of Health. Principal investigator obtained informed consent from each participant or from parents when the patient is less than 18 years old prior to the interview.

\section{Gum arabic administration}

GA in powder form, it is a $100 \%$ natural extract powder produced mechanically from the wildly grown Acacia Senegal tree with a particle size less than $210 \mu \mathrm{m}$. GA in powder form was provided from Dar Savanna Ltd., Khartoum, Sudan. Properties and composition of GA are listed elsewhere [22]. The daily dose was 30 gram. The dose was determined based on previous studies [16, 19]. It was given in one sachet to be consumed early morning dissolved in water for 12 weeks. The GA was provided to the participants every 2 weeks for 3 months (14 sachets per each visit). Empty sachets were retained every visit as indicator of compliance.

Table 1 Demographics and baseline characteristics

\begin{tabular}{|c|c|c|c|c|c|}
\hline Characteristics & Mean & SD & Median & Maximum & Minimum \\
\hline Age & 16.26 & 8.52 & 15 & 42 & 5 \\
\hline Gender & 23(49 \%) Male & & & & \\
\hline Base line weight (Kg) & $35 \cdot 96$ & 14 & $37 \cdot 3$ & 63 & 13 \\
\hline Base line height $(\mathrm{Cm})$ & $148 \cdot 34$ & 20.99 & $154 \cdot 5$ & 107 & 190 \\
\hline $\mathrm{Hb} \mathrm{g} / \mathrm{dL}$ & 7.28 & 1.105 & 7 & 11 & $5 \cdot 5$ \\
\hline $\mathrm{Hb} F(\%)$ & 6.68 & 5.44 & 4.80 & 17.50 & 00 \\
\hline $\mathrm{Hb} S(\%)$ & $89 \cdot 99$ & $5 \cdot 15$ & 91 & $97 \cdot 20$ & $79 \cdot 40$ \\
\hline $\mathrm{Hb} \mathrm{A}(\%)$ & $3 \cdot 33$ & $0 \cdot 52$ & $3 \cdot 3$ & $4 \cdot 4$ & $2 \cdot 5$ \\
\hline
\end{tabular}


Table 2 Comparison between the mean of pre and post intervention values of biomarkers

\begin{tabular}{|c|c|c|c|c|}
\hline Variable & Base line value Mean \pm SD & $\begin{array}{l}\text { Post intervention concentration } \\
\text { value Mean } \pm \text { SD }\end{array}$ & P.V. & $95 \% \mathrm{Cl}$ \\
\hline $\mathrm{Hb} F(\%)$ & $6 \cdot 68 \pm 5.44$ & $7 \cdot 41 \pm 5.38$ & $.000^{b}$ & $0.431-1.028$ \\
\hline $\mathrm{Hb} S(\%)$ & $90 \pm 5 \cdot 15$ & $89 \cdot 24 \pm 5 \cdot 10$ & $.000^{b}$ & $0.455-1.043$ \\
\hline $\mathrm{Hb} \mathrm{A}(\%)$ & $3.3 \pm 0.52$ & $3.33 \pm 0.48$ & 0.901 & $0.064-0.072$ \\
\hline Hemoglobin (g/dL) & $7 \cdot 28 \pm 1 \cdot 105$ & $7.2638 \pm 1.08$ & 0.777 & $-0 \cdot 142-0 \cdot 188$ \\
\hline $\mathrm{MCV}(\mathrm{fL})$ & $85 \cdot 2 \pm 9.37$ & $89 \cdot 20 \pm 12 \cdot 33$ & $.000^{b}$ & $-2.312--6.058$ \\
\hline PCV \% & $20.56 \pm 3.15$ & $21.57 \pm 4.29$ & $.026^{a}$ & $0.124-1.902$ \\
\hline $\mathrm{MCH}$ pg & $30 \cdot 32 \pm 3 \cdot 87$ & $30.01 \pm 4 \cdot 11$ & 0.270 & $-.2496-0 \cdot 871$ \\
\hline $\mathrm{MCHC}(\mathrm{g} / \mathrm{dL})$ & $35 \cdot 2 \pm 2 \cdot 22$ & $33 \cdot 4 \pm 2 \cdot 29$ & $.000^{b}$ & $1.035-2.559$ \\
\hline Reticulocyte count \% & $14 \cdot 412 \pm 4 \cdot 27$ & $16 \cdot 27 \pm 7.03$ & .185 & $-4 \cdot 855-1 \cdot 130$ \\
\hline Platelets counts $10^{3} / \mathrm{uL}$ & $448 \cdot 27 \pm 144 \cdot 79$ & $471 \cdot 36 \pm 169 \cdot 41$ & .346 & $-71 \cdot 94-25 \cdot 76$ \\
\hline WBCs $10^{3} / \mathrm{uL}$ & $16.72 \pm 16 \cdot 3$ & $13.54 \pm 4.68$ & .195 & $-1.682-8.035$ \\
\hline RBCs $10^{6} / \mathrm{uL}$ & $2 \cdot 37 \pm 041$ & $2.42 \pm 0.45$ & .170 & $-0.1091-0.197$ \\
\hline LDH U/L & $717 \cdot 23 \pm 269.95$ & $643 \cdot 14 \pm 244 \cdot 5$ & $.028^{a}$ & $8.22-139.94$ \\
\hline Erythropoietin IU/L & $8.74 \pm 2.96$ & $8.782 \pm 3.92$ & .926 & $-.944-8617$ \\
\hline
\end{tabular}

${ }^{a}$ Difference is significant at the 0.05 level (2-tailed)

${ }^{b}$ Difference is significant at the 0.01 level (2-tailed)

A pre-coded and pre-tested standardized questionnaire and check list were used to collect data about participants' physical examination, weight, height, severity of the symptoms and any side effects. Clinical safety assessments and laboratory tests, complete blood count (CBC) every 2 weeks using automated cell counter (Sysmex) were regularly conducted. In addition serum chemistry including renal function tests (RFT) and Liver function test (LFT) were carried out every 4 weeks. Regular follow up was carried by the consultant physician in the unit.

Hemoglobin $\mathrm{F}$ was measured by modified fully automated capillary2 flexpiercing hemoglobin electrophoresis technique (Sepia France) prior to starting GA and then every 4 weeks. Plasma was separated from EDTA sample and used for measurement of Erythropoietin (EPO) level by enzyme-linked immunosorbent assay (ELISA) using "Wkea, USA" EPO kit.

Data were analyzed using SPSS version 20. Paired samples $T$ test was used to compare between pre and post intervention results. $P$ values equal or less than 0.05 was considered significant.

\section{Results}

A total of 47 patients were enrolled (Table 1) between April, 2014 (first subject enrolled) to January, 2015 (last

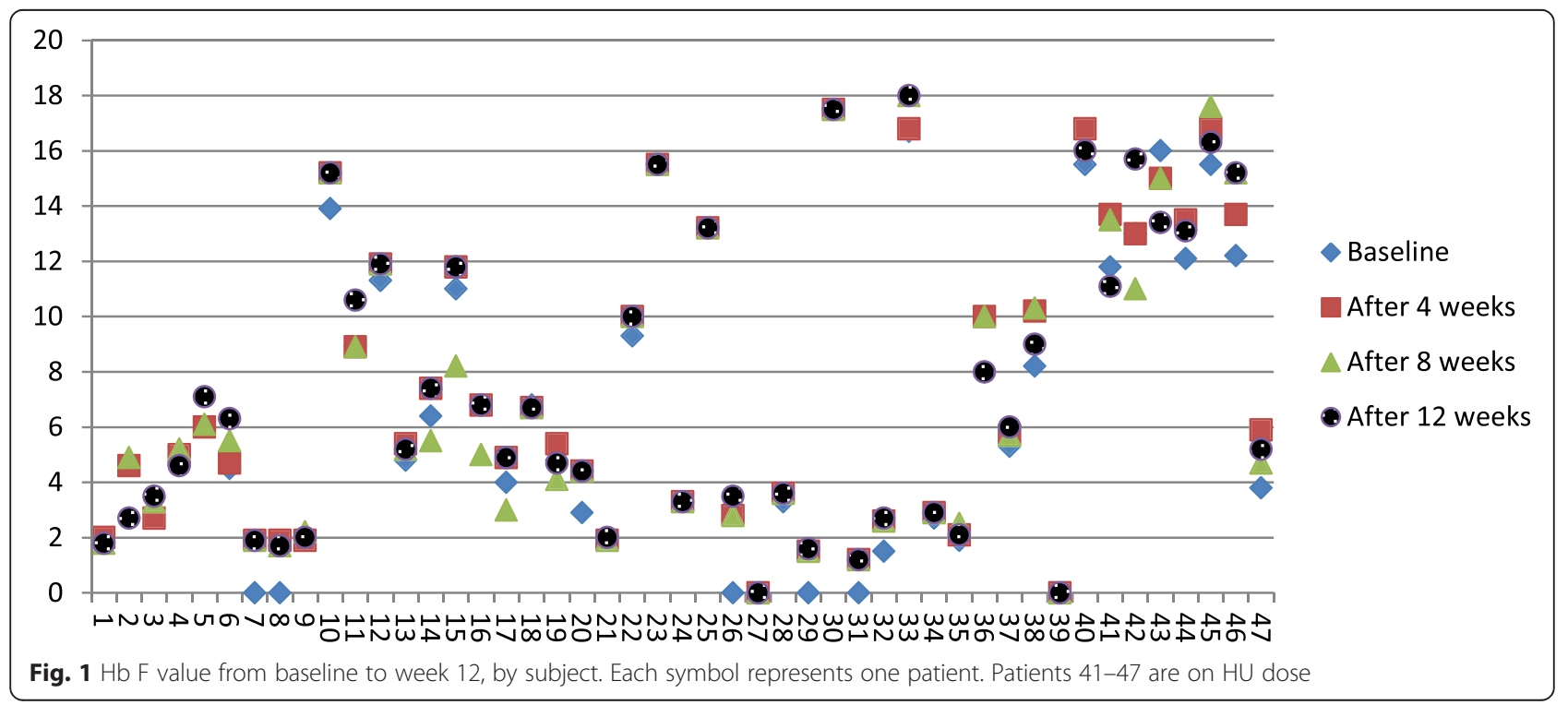


Table 3 Side effects of intervention among study group

\begin{tabular}{lllllll}
\hline Complain & \multicolumn{2}{l}{ Yes } & & & NO & Total \\
\cline { 2 - 3 } & $\mathrm{N}$ & $\%$ & & $\mathrm{~N}$ & $\%$ & \\
\hline Bloating & 7 & 15 & & 40 & 85 & 47 \\
Diarrhea & 9 & 19 & & 38 & 81 & 47 \\
Vomiting & 7 & 15 & & 40 & 85 & 47 \\
Nausea & 3 & 6 & & 44 & 94 & 47 \\
\hline
\end{tabular}

patient last visit) when adequate data were collected to allow for planning for further study. All were Sudanese; 23 were males (age 5 to 42 years). Seven patients were on a stable dose of hydroxyurea 500 gram per day.

Duration of treatment was for 12 weeks except two patients received GA for 9 weeks and eight patients for 10 weeks. The last recorded results were considered for final analysis as post treatment results. Four patients were excluded because of blood transfusion during first 2 weeks of the study. One patient taking GA for 10 weeks was excluded because he developed severe malaria requiring blood transfusion.

Daily oral intake of GA significantly increased $\mathrm{HbF}$ level, MCV and hematocrit (Table 2). Peak HbF was recorded after 4 weeks and sustained till week 12 for most of the patients (Fig. 1 and Additional file 1). GA treatment was not followed by significant increase in hemoglobin concentration or $\mathrm{MCH}$ (Table 2). There was no significant change in WBC counts or Reticulocyte count (Table 2) and no significant increase in Erythropoietin level. A positive correlation was observed between absolute change in $\operatorname{HbF}(\Delta \mathrm{F})$ level and Erythropoietin level ( $\triangle$ Epo) (Pearson Correlation. 383, P. value $0.0495 \%$ CI $0 \cdot 019$ to $0 \cdot 66$ ). Thirteen patients (28\%) have been admitted once to hospital while two patients were admitted twice. All were admitted for $24 \mathrm{~h}$ because of painful crisis. One patient has chronic leg ulcer healed after taking GA. There was a significant increase from base line weight by mean of $1.87 \mathrm{Kg}$ (P.V:0 $.000195 \%$ CI $1 \cdot 24$ to $2 \cdot 49$ )

\section{GA tolerance and side effects}

$37 \%$ of patients complained from side effects such as bloating, diarrhea, nausea, and vomiting (Table 3). All these symptoms resolved spontaneously within the first 5 days. The mother of a female 5 year old patient reported that GA treatment of the child was followed by appearance of loose stool; a condition did not require intervention.

\section{Discussion}

Sickle Cell Disease is the most common hemoglobin defect around the globe, with a high incidence in subSaharan Africa [9]. This necessitates the search for nontoxic oral and cheap therapeutic agents that increase fetal globin expression, and are tolerable for patients with minimal side effects.

According to the present study GA increases the level of $\mathrm{HbF}$ and significantly decreases level of $\mathrm{HbS}$ (Table 2). Since $\mathrm{HbS}$ polymerization depends on its intracellular concentration, a slight reduction is likely to have a beneficial effect on the kinetic of polymerization [25]. GA has no effect on $\mathrm{HbA}_{2}$ (P.V: 0.9), and this is expected,in spite delta chain is located in chromosome 11 like beta and gamma chains [26]. Butyrate exposure results in true reversal of switch from beta to gamma globin expression [12]. Exposure to GA increases MCV (Table 2, Fig. 2) mimicking the effect of hydroxyurea therapy [4, 6, 27-31]. Increase in $\mathrm{MCV}$ is linked to the increase in intracellular $\mathrm{HbF}$ [32] and an increase in hemoglobin F is always associated with a concomitant increase in $\operatorname{MCV}[27,32]$.

GA significantly decreased the $\mathrm{MCHC}$ value (Table 2 Fig. 3), an effect again mimicking effects of $\mathrm{HU}[27,30]$. Reduction in MCHC is beneficial in SCA patients since it

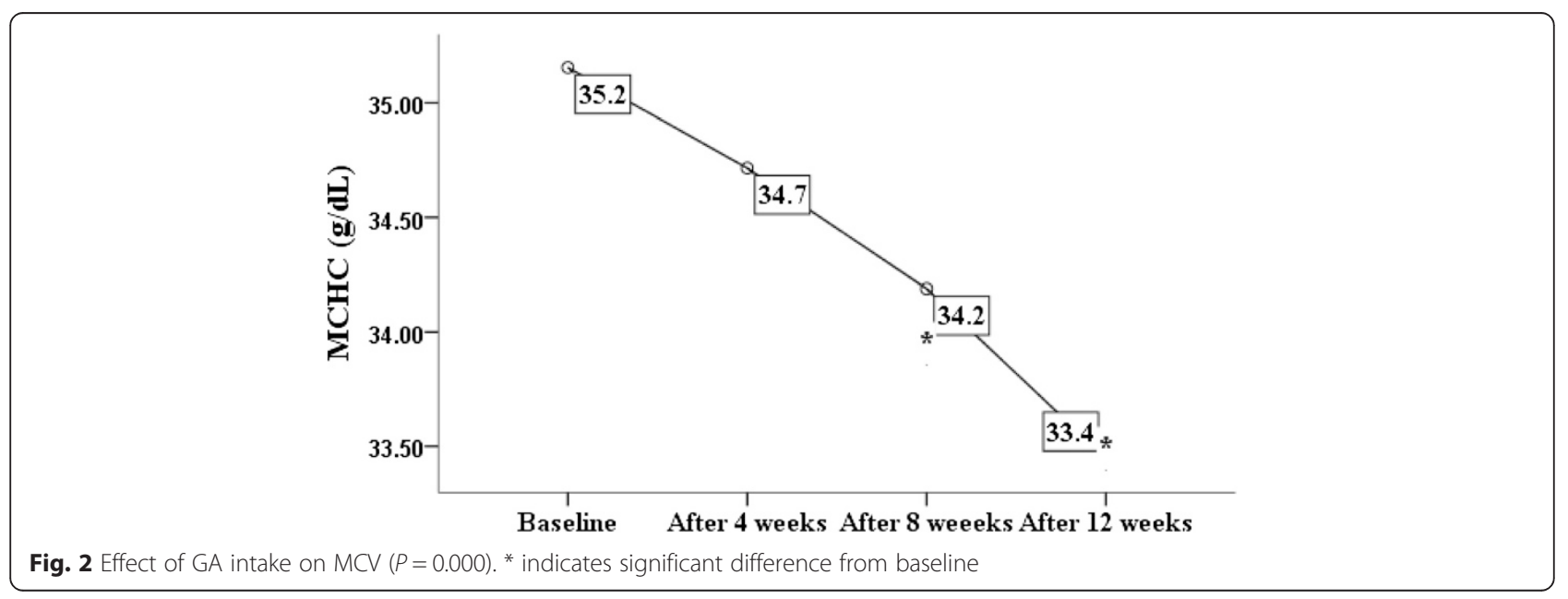




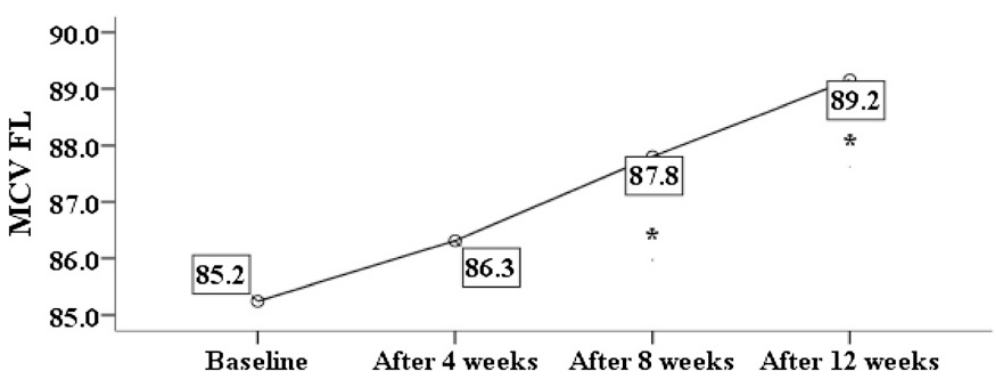

Fig. 3 Effect of GA intake on MCHC $(P=0.000)$. * indicates significant difference from baseline

inhibits hemoglobin S polymerization [3, 26]. GA intake did not increase hemoglobin concentration (Table 2). Total hemoglobin is increased in clinical studies following administration of parental drugs such as: 5-azacytidine, decitabine, and butyrate given for longer periods, since they allowed HbF cells to accumulate and survive [33]. Sickle cell patients have elevated lactate dehydrogenase enzyme (LDH) levels, a biological marker reflecting intravascular hemolysis $[3,34,35]$. Oral consumption of GA decreased LDH levels (Table 2). GA daily dose had no effect on Erythropoietin level and there was no significant increase in RBCs count. However, the changes in EPO and $\mathrm{HbF}$ levels were significantly correlated. Recombinant Erythropoietin alone [36] or in combination with HU [37] is an effective stimulator of fetal hemoglobin production.

This study revealed a novel effect of GA, as oral HbF inducing agent alone or in combination with HU. While HU has a variable therapeutic response [1], in this study $53 \%$ of participants showed response. GA ingestion increase $\mathrm{HbF} \%$ even in very low baseline $\mathrm{HbF} \%$ patients. Seven patients with undetectable $\mathrm{HbF}$ as measured by electrophoresis, five patients showed elevation of $\mathrm{HbF} \%$, absolute change range: $(1 \cdot 2-3 \cdot 5)$. The five respondents were less than 10 years old. The other non-respondents aged 36 and 22. This result showed GA intake may have better response among younger patients.

GA can be utilized as natural safe source of short chain fatty acids by sickle cell anemia patients. In spite of mild effect of GA as fetal inducing agent this effect could be substantial. Patients who had HbF values more than $2 \%$ had a 10 -year probability of survival of $89 \%$, compared with $53 \%$ among patients with $\mathrm{HbF}$ lower than $2 \%$ [4].

\section{Conclusion}

In conclusion GA found to increase the percentage of fetal hemoglobin and MCV and decrease MCHC. GA showed no effect on hemoglobin concentration and leucocytes counts.

One of the limitations in our study is not measuring serum butyrate concentration due to resource limitation.
Another major limitation in this study we didn't analyze the effect of GA on gene expression, again because of resource limitation.

This data sheds light on a new era of SCD management that worth further studies. Long duration clinical trials (more than 6 months) and multi arms will be beneficial to assess the sustainability of increase in $\mathrm{HbF}$ and its advantages on clinical events and disease severity.

\section{Additional file}

Additional file 1: Percentage of $\mathrm{HbF}$ of individual subjects. (PDF $36 \mathrm{~kb}$ )

\section{Competing interests}

No conflicts of interest, financial or otherwise, are declared by the authors.

\section{Authors' contributions}

LK, IF, FL and AS participated in study design. LK, IF and AS were involved in all aspects of the study conduct. LK, AS, IF, FL and MN participated in the writing and review of the manuscript. LK and MN analyzed data. LK and IF performed laboratory studies. OE and HE were significant clinical contributors to the study. All authors approved final version of manuscript.

\section{Acknowledgement}

We would like to thank Dr Mohamed Ahmed Alfeel and Dr Yasir Abdeen from Central Laboratory unit Military hospital for their technical assistance in $\mathrm{HbF}$ measurements. We would like to thank Dar Savanna Ltd. Khartoum, Sudan (www.naturegums.com). This research is funded by governmental fund as grant from Higher Education and Scientific Research Ministry. And supporting fund for the principal investigator (LK) from Alneelain University Khartoum Sudan.

\section{Author details}

${ }^{1}$ Department of Physiology Faculty of Medicine, Alneelain University, P.O. Box: 11121, Khartoum 12702, Sudan. ${ }^{2}$ Alneelain Research Centre Faculty of Medicine, Alneelain University, Khartoum, Sudan. ${ }^{3}$ Department of Hematology, Military Hospital, Khartoum, Sudan. ${ }^{4}$ Department of Pediatrics, Military Hospital, Khartoum, Sudan. ${ }^{5}$ Department of Community Medicine Faculty of Medicine, Alneelain University, Khartoum, Sudan. ${ }^{6}$ Department of Physiology, University of Tübingen, Tübingen, Germany. ${ }^{7}$ Department of Physiology Faculty of Medicine, University of Khartoum, Khartoum, Sudan.

Received: 2 May 2015 Accepted: 10 December 2015 Published online: 29 December 2015

\section{References}

1. Fathallah $\mathrm{H}$, Atweh GF. Induction of fetal hemoglobin in the treatment of sickle cell disease. Hematology Am Soc Hematol Educ Program 2006;58-62.

2. Lang E, Lang F. Triggers, inhibitors, mechanisms, and significance of eryptosis: The suicidal erythrocyte death. Biomed Res Int. 2015;2015:513518. 
3. Little JA, Hauser KP, Martyr SE, Harris A, Maric I, Morris CR, et al. Hematologic, biochemical, and cardiopulmonary effects of L-arginine supplementation or phosphodiesterase 5 inhibition in patients with sickle cell disease who are on hydroxyurea therapy. Eur J Haematol. 2009;82(4):315-21.

4. Silva-Pinto AC, Angulo IL, Brunetta DM, Neves Fl, Bassi SC, Santis GC, et al. Clinical and hematological effects of hydroxyurea therapy in sickle cell patients: A single-center experience in Brazil. Sao Paulo Med J. 2013;131(4):238-43.

5. Akinsheye I, Alsultan A, Solovieff N, Ngo D, Baldwin CT, Sebastiani $P$, et al. Fetal hemoglobin in sickle cell anemia. Blood. 2011;118(1):19-27.

6. Ware RE, Eggleston B, Redding-Lallinger R, Wang WC, Smith-Whitley K, Daeschner C, et al. Predictors of fetal hemoglobin response in children with sickle cell anemia receiving hydroxyurea therapy. Blood. 2002;99(1):10-4.

7. Ware RE, Aygun B. Advances in the use of hydroxyurea. Hematology Am Soc Hematol Educ Program 2009;62-9. doi: 10.1182/asheducation-2009.1.62.

8. Kutlar A, Reid ME, Inati A, Taher AT, Abboud MR, El-Beshlawy A, et al. A dose-escalation phase lla study of 2,2-dimethylbutyrate (HQK-1001), an oral fetal globin inducer, in sickle cell disease. Am J Hematol. 2013;88(11):E255-60

9. Diallo DA, Guindo A. Sickle cell disease in sub-Saharan Africa: Stakes and strategies for control of the disease. Curr Opin Hematol. 2014;21(3):210-4.

10. Atweh GF, Sutton M, Nassif I, Boosalis V, Dover GJ, Wallenstein S, et al. Sustained induction of fetal hemoglobin by pulse butyrate therapy in sickle cell disease. Blood. 1999;93(6):1790-7.

11. Dover GJ, Brusilow S, Samid D. Increased fetal hemoglobin in patients receiving sodium 4-phenylbutyrate. N Engl J Med. 1992;327(8):569-70.

12. Fathallah $H$, Weinberg RS, Galperin $Y$, Sutton M, Atweh GF. Role of epigenetic modifications in normal globin gene regulation and butyratemediated induction of fetal hemoglobin. Blood. 2007;110(9):3391-7.

13. Hines P, Dover GJ, Resar LM. Pulsed-dosing with oral sodium phenylbutyrate increases hemoglobin $\mathrm{F}$ in a patient with sickle cell anemia. Pediatr Blood Cancer. 2008;50(2):357-9.

14. Resar LM, Segal JB, Fitzpatric LK, Friedmann A, Brusilow SW, Dover GJ. Induction of fetal hemoglobin synthesis in children with sickle cell anemia on low-dose oral sodium phenylbutyrate therapy. J Pediatr Hematol Oncol. 2002;24(9):737-41.

15. Ali BH, Ziada A, Blunden G. Biological effects of gum arabic: A review of some recent research. Food Chem Toxicol. 2009;47(1):1-8.

16. Babiker R, Merghani TH, Elmusharaf K, Badi RM, Lang F, Saeed AM. Effects of Gum Arabic ingestion on body mass index and body fat percentage in healthy adult females: two-arm randomized, placebo controlled, doubleblind trial. Nutr J. 2012;11:111.

17. Ballal A, Bobbala D, Qadri SM, Foller M, Kempe D, Nasir O, et al. Anti-malarial effect of gum arabic. Malar J. 2011;10:139.

18. Tulung B, Remesy C, Demigne C. Specific effect of guar gum or gum arabic on adaptation of cecal digestion to high fiber diets in the rat. J Nutr. 1987;117(9):1556-61

19. Matsumoto N, Riley S, Fraser D, Al-Assaf S, Ishimura E, Wolever T, et al. Butyrate modulates TGF-beta1 generation and function: Potential renal benefit for Acacia(sen) SUPERGUM (gum arabic)? Kidney Int. 2006;69(2):257-65.

20. Nasir O. Renal and extrarenal effects of gum arabic (Acacia senegal)-what can be learned from animal experiments? Kidney Blood Press Res. 2013;37(4-5):269-79.

21. Ali BH, Al-Husseni I, Beegam S, Al-Shukaili A, Nemmar A, Schierling S, et al. Effect of gum arabic on oxidative stress and inflammation in adenineinduced chronic renal failure in rats. PLoS One. 2013;8(2):e55242.

22. Nasir O, Umbach AT, Rexhepaj R, Ackermann TF, Bhandaru M, Ebrahim A, et al. Effects of gum arabic (Acacia senegal) on renal function in diabetic mice. Kidney Blood Press Res. 2012;35(5):365-72.

23. Ali BH, Al ZaGÇÖabi M, Ramkumar A, Yasin J, Nemmar A. Anemia in adenine-induced chronic renal failure and the influence of treatment with gum acacia thereon. Physiol Res. 2014;63(3):351-8.

24. Ali BH, Beegam S, Al Lawati I, Waly MI, Nemmar A. Comparative efficacy of three brands of gum arabic on adenineGÇôinduced chronic renal failure in rats. Physiol Res. 2013;62(1):47-56.

25. de FL, Corrocher R. Established and experimental treatments for sickle cell disease. Haematologica. 2004;89(3):348-56.

26. Schechter AN. Hemoglobin research and the origins of molecular medicine. Blood. 2008;112(10):3927-38.
27. Orringer EP, Blythe DS, Johnson AE, Phillips Jr G, Dover GJ, Parker JC. Effects of hydroxyurea on hemoglobin $\mathrm{F}$ and water content in the red blood cells of dogs and of patients with sickle cell anemia. Blood. 1991;78(1):212-6.

28. Ferster A, Tahriri P, Vermylen C, Sturbois G, Corazza F, Fondu P, et al. Five years of experience with hydroxyurea in children and young adults with sickle cell disease. Blood. 2001;97(11):3628-32.

29. Zimmerman SA, Schultz WH, Davis JS, Pickens CV, Mortier NA, Howard TA et al. Sustained long-term hematologic efficacy of hydroxyurea at maximum tolerated dose in children with sickle cell disease. Blood. 2004; 103(6):2039-45.

30. Steinberg MH, Nagel RL, Brugnara C. Cellular effects of hydroxyurea in $\mathrm{Hb}$ SC disease. Br J Haematol. 1997;98(4):838-44.

31. Kinney TR, Helms RW, O'Branski EE, Ohene-Frempong K, Wang W, Daeschner C, et al. Safety of hydroxyurea in children with sickle cell anemia: Results of the HUG-KIDS study, a phase I/II trial. Pediatr Hydroxyurea Group Blood. 1999;94(5):1550-4

32. Steinberg MH, Voskaridou E, Kutlar A, Loukopoulos D, Koshy M, Ballas SK, et al. Concordant fetal hemoglobin response to hydroxyurea in siblings with sickle cell disease. Am J Hematol. 2003;72(2):121-6.

33. Fucharoen S, Inati A, Siritanaratku N, Thein SL, Wargin WC, Koussa S, et al. A randomized phase I/II trial of HQK-1001, an oral fetal globin gene inducer, in beta-thalassaemia intermedia and $\mathrm{HbE}$ /beta-thalassaemia. $\mathrm{Br} \mathrm{J}$ Haematol. 2013;161(4):587-93.

34. Bartolucci P, Brugnara C, Teixeira-Pinto A, Pissard S, Moradkhani $K$, Jouault $H_{4}$ et al. Erythrocyte density in sickle cell syndromes is associated with specific clinical manifestations and hemolysis. Blood. 2012;120(15):3136-41.

35. Ballas SK, Marcolina MJ. Hyperhemolysis during the evolution of uncomplicated acute painful episodes in patients with sickle cell anemia. Transfusion. 2006;46(1):105-10.

36. Nagel RL, Vichinsky E, Shah M, Johnson R, Spadacino E, Fabry ME, et al. F reticulocyte response in sickle cell anemia treated with recombinant human erythropoietin: a double-blind study. Blood. 1993;81(1):9-14.

37. Rodgers GP, Dover GJ, Uyesaka N, Noguchi CT, Schechter AN, Nienhuis AW. Augmentation by erythropoietin of the fetal-hemoglobin response to hydroxyurea in sickle cell disease. N Engl J Med. 1993;328(2):73-80.

\section{Submit your next manuscript to BioMed Central and we will help you at every step:}

- We accept pre-submission inquiries

- Our selector tool helps you to find the most relevant journal

- We provide round the clock customer support

- Convenient online submission

- Thorough peer review

- Inclusion in PubMed and all major indexing services

- Maximum visibility for your research

Submit your manuscript at www.biomedcentral.com/submit
) Biomed Central 